\title{
IL-18 LEVELS IN NASAL LAVAGE AFTER INHALATORY CHALLENGE TEST WITH FLOUR IN BAKERS DIAGNOSED WITH OCCUPATIONAL ASTHMA
}

\author{
ANNA KRAKOWIAK ${ }^{1}$, JOLANTA WALUSIAK ${ }^{1}$, PATRYCJA KRAWCZYK ${ }^{1}$, MARTA WISZNIEWSKA ${ }^{1}$, \\ WOJCIECH DUDEK ${ }^{2}$, TOMASZ WITTCZAK ${ }^{1}$, and CEZARY PAŁCZYŃSKI ${ }^{1,2}$
}

${ }^{1}$ Nofer Institute of Occupational Medicine, Łódź, Poland

Department of Occupational Diseases

${ }^{2}$ Nofer Institute of Occupational Medicine, Łódź, Poland

Centre of Occupational and Environmental Allergy

\begin{abstract}
Objectives: The authors discuss the outcomes of a study on IL-18 concentration in nasal washings after the inhalatory challenge test with flour allergens (ICHT-F) in bakers with flour-induced occupational airway allergy (OAA) Methods: We measured IL-18 concentration using ELISA kit and assessed morphological changes in nasal lavage fluid (NLF) before, and $4 \mathrm{~h}$ and $24 \mathrm{~h}$ after ICHT-F in three groups of subjects: Group $\mathrm{A}-9$ patients with diagnosed OAA (occupational asthma and rhinitis), Group B -10 patients with atopic asthma and rhinitis, and Group C -9 healthy volunteers. Results: In Group A, significant differences in the basophil proportion in NLF were noted only $24 \mathrm{~h}$ after ICHT-F. Both the basophil proportion and total eosinophil count were higher in Group A than in Group C at this time-point. Group A also showed a statistically significant increase in IL-18 levels $4 \mathrm{~h}$ after the challenge. A significant relationship was noted between the proportion of basophils $4 \mathrm{~h}$ after ICHT-F and IL-18 level at $24 \mathrm{~h}$ after the test. Conclusions: This is the first study demonstrating an increased expression of IL-18 in nasal washings of subjects diagnosed with OAA to flour allergens. The observed higher concentrations of IL-18 in nasal washings after ICHT as well as the increase in the proportion of basophils provide evidence for the important role of IL-18 in persistent allergic inflammation.
\end{abstract}

Key words:

IL-18, Diagnostics, Occupational asthma

\section{INTRODUCTION}

Interleukin (IL)-18 has been identified as a cytokine stimulating the production of both Th1 and Th2 cytokines [1,2]. IL-18 markedly induces generation of IFN- $\gamma$ from Th1 cells in the presence of anti-D3 and IL-12 [2,3]. Acting together with IL-12, interleukin-18 inhibits in vitro the production of $\mathrm{IgE}$ by inducing IFN- $\gamma$ from activated $B$ cells [4]. Recent reports indicate that this cytokine may also enhance antigen-induced eosinophil recruitment into airways in mice, which implies that it may contribute to the development of airway inflammation in asthma [5]. Allergic inflammation involves a great number of cells playing major roles, these including eosinophils, mast cells, T-lymphocytes, neutrophils, macrophages, epithelial cells, and endothelial cells [6]. All of these cell types have been associated with asthma and allergic rhinitis [6]. Verhaeghe et al. [7] noted an increased expression of IL-18 in nasal secretions of patients with allergic rhinitis during the pollen season compared to baseline values, which addition-

Received: January 31, 2008. Accepted: April 1, 2008.

Address reprint requests to A. Krakowiak, MD, PhD, Department of Occupational Diseases, Nofer Institute of Occupational Medicine, św. Teresy 8, 91-348 Łódź, Poland (e-mail: annakrak@imp.lodz.pl). 
ally supports its important role in regulating eosinophil activation.

Our earlier study [8] indicates that eosinophils and basophils are the predominant cells in the nasal lavage fluid (NLF) of patients with occupational airway allergy (OAA) due to flour allergens. These allergens are a common cause of occupational asthma (OA) [8-10].

To this date, the function of IL-18 in the pathogenesis of OAA has not been elucidated. Therefore, to better understand the role of this cytokine in the development of OAA, we analyzed IL-18 levels and morphological changes in NLF of subjects with flour-induced OAA, before and after the inhalatory challenge test with flour (ICHT-F).

\section{MATERIALS AND METHODS}

\section{Subjects}

Three groups of non-smoking subjects were enrolled in the study. The selection criteria are presented in Table 1. Group A comprised 9 bakers (mean age $40.9 \pm 9.2$ years) with respiratory symptoms - rhinitis and bronchial asthma related to occupational exposure, who were sensitized to occupational allergens (positive skin prick test (SPT) and/or serum IgE). Six bakers showed atopy expressed as a positive result of SPT with common aeroallergens.

Group B consisted of 10 atopic patients (mean age $37.9 \pm 6.4$ years) with perennial respiratory symptoms (rhinitis and bronchial asthma), not occupationally exposed to flour, who showed positive results of SPT with common aeroallergens.
Group Cwere 9 healthyindividuals (mean age $45 \pm 7.8$ years). The controls (Groups B and C) were not sensitized to flour allergens.

The local Biomedical Ethics Committee approved the study protocol, and all the participants submitted their informed consent prior to the study.

\section{Skin prick tests}

Skin prick tests (SPTs) were performed on the volar part of the forearm, with a standard battery of common and occupational allergens, including tree and grass pollens, Dermatophagoides pteronyssinus, D. farinae, moulds, feathers, and occupational allergens (threshing, oatmeal, wheat, corn, barley, rye flour and $\alpha$-amylase (Allergopharma, Reinbek, Germany). Negative control was a commercially available allergen diluent (containing $9 \mathrm{mg}$ $\mathrm{NaCl}, 4 \mathrm{mg}$ phenol and $63 \mathrm{mg}$ glycerol $/ \mathrm{ml}$ ), while $1 \mathrm{mg} / \mathrm{ml}$ solution of histamine dihydrochloride was used as a positive control. SPTs were performed according to a standardized technique [11]. Wheal diameter was assessed after $15 \mathrm{~min}$. Positive reaction was defined as a wheal diameter of at least $3 \mathrm{~mm}$ in the absence of reaction to the diluent and in the presence of a positive reaction to histamine.

\section{Total and specific IgE}

Total serum immunoglobulin ( $\operatorname{IgE}$ ) was evaluated using UniCAP system (Pharmacia Diagnostics, Uppsala, Sweden). The presence of specific serum $\operatorname{IgE}(\mathrm{s} \operatorname{IgE})$ against occupational allergens: wheat flour, soya flour, $\alpha$-amylase, Sitophilus granarius (pax 4); wheat flour, rye flour, rice

Table 1. Selection criteria for the study groups

\begin{tabular}{lcccc}
\hline Group & Number of subjects & $\begin{array}{c}\text { Positive SPT to common } \\
\text { allergens }\end{array}$ & $\begin{array}{c}\text { Positive SPT } \\
\text { and/or serum IgE } \\
\text { to occupational } \\
\text { allergens (flour) }\end{array}$ & $\begin{array}{c}\text { Allergic symptoms in } \\
\text { workplace closely related } \\
\text { to flour exposure }\end{array}$ \\
\hline A & 9 & 6 & 9 & 9 \\
B & 10 & 10 & 0 & 0 \\
C & 9 & 0 & 0 & 0 \\
\hline
\end{tabular}

A - bakers with respiratory symptoms - rhinitis and bronchial asthma related to occupational exposure. B - atopic patients with perennial respiratory symptoms - rhinitis and bronchial asthma, not occupationally exposed to flour. $\mathrm{C}$ - healthy individuals. SPT - skin prick test. 
flour, barley flour (fx 20) and for: wheat flour, oat flour, maize flour, sesame flour (fx3) was also analyzed (UniCAP, Pharmacia Diagnostics, Uppsala, Sweden).

The detection limit was $0.35 \mathrm{kU} / \mathrm{l}$. Values $<0.35 \mathrm{kU} / \mathrm{l}$ represent a negative result, while values $\geq 0.35 \mathrm{kU} / 1$ a positive result.

\section{Diagnostic criteria}

Hypersensitivity to any allergen has been defined as at least one positive result of SPT or positivity of the specific serum IgE assay [12]. The symptoms were considered to be work-related if they had developed after a contact with an occupational agent and improved during weekends or holidays $[12,13]$. In our study, OA was diagnosed in the sensitized subjects reporting work-related chest symptoms who developed early or dual asthmatic reaction after exposure to occupational allergens.

Diagnosis of occupational allergic rhinitis was based on questionnaire data and positive nasal response to the provocation test $[14,15]$.

\section{Study protocol and challenge procedure}

The bronchial challenge test was performed in an inhalation chamber - the subjects were instructed to sift approximately $100 \mathrm{~g}$ of wheat, rye, corn, barley, and oatmeal flour. The whole challenge lasted $30 \mathrm{~min}$. Each subject had nasal lavage performed three times: immediately before ICHT-F, and at $4 \mathrm{~h}$ and $24 \mathrm{~h}$ after the provocation.

\section{Nasal challenge technique}

Before the provocation, each nostril was washed 10 times with $5 \mathrm{ml}$ of saline solution using the 'nasal pool' device a $5 \mathrm{ml}$ syringe closely fitting the nostril. Nasal washings were collected immediately before the provocation and at $4 \mathrm{~h}$ and $24 \mathrm{~h}$ afterwards. $5 \mathrm{ml}$ saline was injected into the nasal cavity for $5 \mathrm{~min}$ and then recovered. The washings were always collected from the same side of the nasal cavity. Nasal symptom score was assessed before, during, and after ICHT-F. The number of sneezes and the degree of mucosal edema, rhinorrhea and itching were evaluated. The total symptom score ranged from 0 to 8 and represented the sum of the scores for sneezing $(0$ sneezes -0 points,
1-4 sneezes -1 point, $>4$ sneezes -2 points), rhinorrhea (none -0 points, mild -1 point, abundant -2 points), mucosal edema (none -0 points, mild -1 point, nasal block -2 points) and itching (none -0 points, itching of the nose or throat -1 point, itching of the nose and throat -2 points) [14]. The scores for the nasal and eye symptoms were considered positive at values $\geq 3$.

Cellular composition of nasal washings was analyzed. All the procedures were performed as in the 'nasal pool' method [16]. The processing of nasal washings has been described elsewhere [17].

\section{IL-18 in nasal lavage fluid}

IL-18 concentrations were measured before, and $4 \mathrm{~h}$ and $24 \mathrm{~h}$ after ICHT-F by enzyme-linked immunosorbent assay (ELISA) using commercially available kits (sensitivity $12.5 \mathrm{pg} / \mathrm{ml}$ ) (Quantikine, R\&D Systems, Inc, MN, USA). For statistical analysis, the concentrations below the detection limit were assumed to be null.

\section{Statistical analysis}

The data were analyzed using parametric two-way ANOVA and Tukey's test for multiple comparisons. The differences were considered significant at $\mathrm{P}<0.05$. Correlations between two variables were examined using Spearman's correlation coefficient.

\section{RESULTS}

\section{Morphological changes in NLF after ICHT-F}

The provocation produced no statistically significant changes in the total basophil and eosinophil counts in NLF from any group at any time-point (Figs. 1, 2). The above referred also to the total leukocyte count in NLF.

In Group A, significant differences were noted in the proportion of epithelial cells. The percentage of these cells was significantly higher before the challenge than $4 \mathrm{~h}$ and $24 \mathrm{~h}$ afterwards $\left(\mathrm{F}_{2.24}=6.53, \mathrm{p}<0.05\right)$. Basophil proportion was also significantly higher $\left(\mathrm{F}_{2.24}=4.64, \mathrm{p}<0.05\right) 24 \mathrm{~h}$ after the challenge than before the test (Fig. 3). No significant differences could be found either in the eosinophil or neutrophil proportion (Figs. 4, 5). 


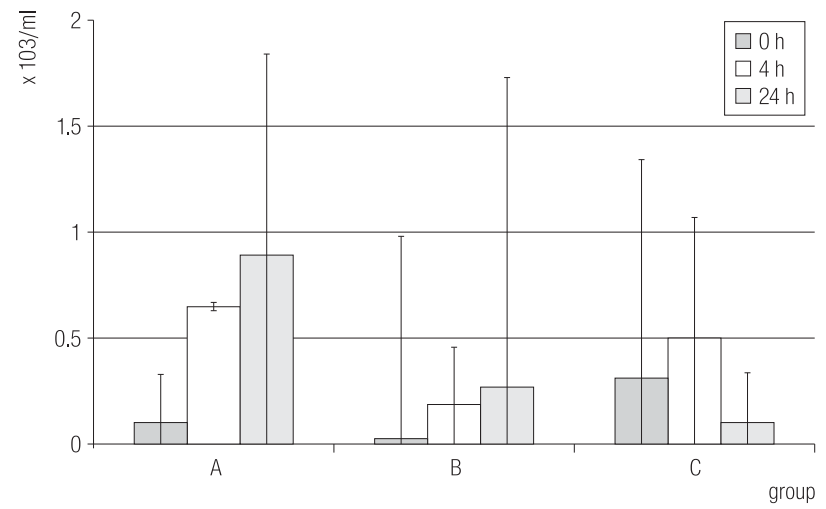

Fig. 1. Changes in total basophil count induced by inhalatory challenge test with flour allergens (ICHT-F).

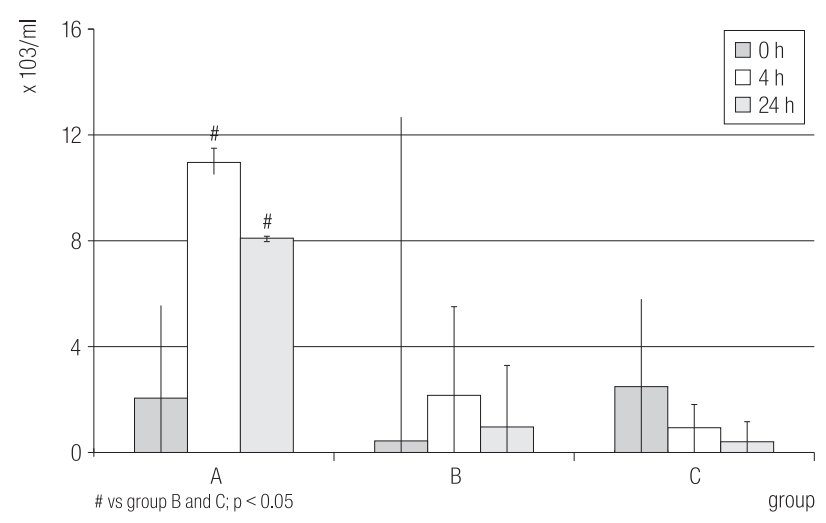

Fig. 2. Changes in total eosinophil count induced by ICHT-F.

As regards the patients from Group B, the percentage of epithelial cells at both the time-points after provocation ( $4 \mathrm{~h}$ and $24 \mathrm{~h}$ ) was significantly lower than before the test $\left(\mathrm{F}_{2.27}=8.76, \mathrm{p}<0.05\right)$. Neutrophil proportion was found to be significantly increased $24 \mathrm{~h}$ after ICHT $\left(\mathrm{F}_{2.27}=3.59\right.$; $\mathrm{p}<0.05$ ) (Fig. 5). No significant differences were noted in the eosinophil and basophil proportion in nasal washings at any time point (Figs. 3, 4).

In Group $\mathrm{C}$, the percentage of epithelial cells was higher before the provocation than $24 \mathrm{~h}$ after the test $\left(\mathrm{F}_{2.24}=5.22\right.$, $\mathrm{p}<0.05$ ). An analysis of the proportion of neutrophils revealed a significant increase $24 \mathrm{~h}$ after the challenge $\left(\mathrm{F}_{2.24}=5.07 ; \mathrm{p}<0.05\right)$ (Fig. 5). ICHT-F did not induce statistically significant changes in the proportion of basophils or eosinophils in nasal washings from that group at any time-point (Figs. 3, 4).

An assessment of the total eosinophil count revealed significant differences between the groups at the $4 \mathrm{~h}$ $\left(\mathrm{F}_{2.25}=5.03, \mathrm{p}<0.05\right)$ and $24 \mathrm{~h}\left(\mathrm{~F}_{2.25}=14.9, \mathrm{p}<0.05\right)$

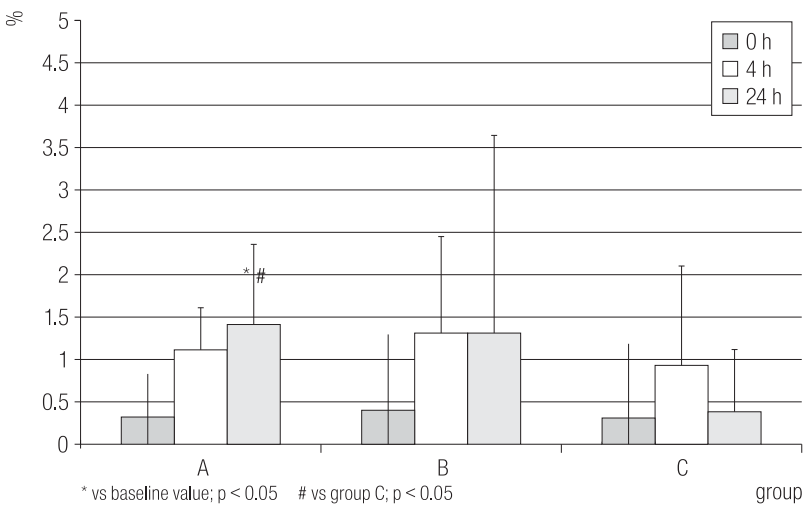

Fig. 3. Changes in basophil proportion after ICHT-F.

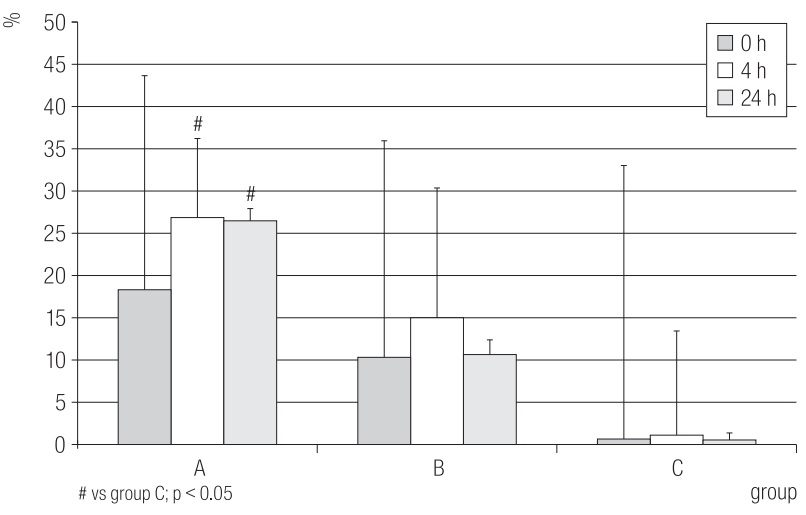

Fig. 4. Changes in eosinophil proportion after ICHT-F.

time-points (Fig. 2). The total eosinophil count was statistically higher in Group A than in Group B or C. Eosinophil proportion was higher in Group A than in Group $\mathrm{C}$ at the $4 \mathrm{~h}$ and $24 \mathrm{~h}$ time-points $\left(\mathrm{F}_{2.25}=5.10\right.$ and $\mathrm{F}_{2.25}=3.97$, respectively; $\mathrm{p}<0.05)$ (Fig. 4).

The authors also found a significant between-group difference in the basophil proportion; $24 \mathrm{~h}$ after ICHT-F, the proportion of these cells was higher in Group A than in Group C $\left(\mathrm{F}_{2.25}=4.08, \mathrm{p}<0.05\right)$ (Fig. 3).

\section{IL-18 levels in NLF after ICHT-F}

ICHT-Finduced statistically significant changes in IL-18 level in the subjects diagnosed with OAA (Group A) $\left(\mathrm{F}_{2.24}=9.22\right.$; $\mathrm{p}<0.05) ; 4 \mathrm{~h}$ after the challenge, the level of IL-18 was higher than before the test and $24 \mathrm{~h}$ afterwards (Fig. 6).

No significant difference in IL-18 level could be found between Group B and C (Fig. 6). Significant between-group differences were also observed with respect to IL-18 level before the provocation $\left(\mathrm{F}_{2.25}=5.26 ; \mathrm{p}<0.05\right)$; in Group B, 


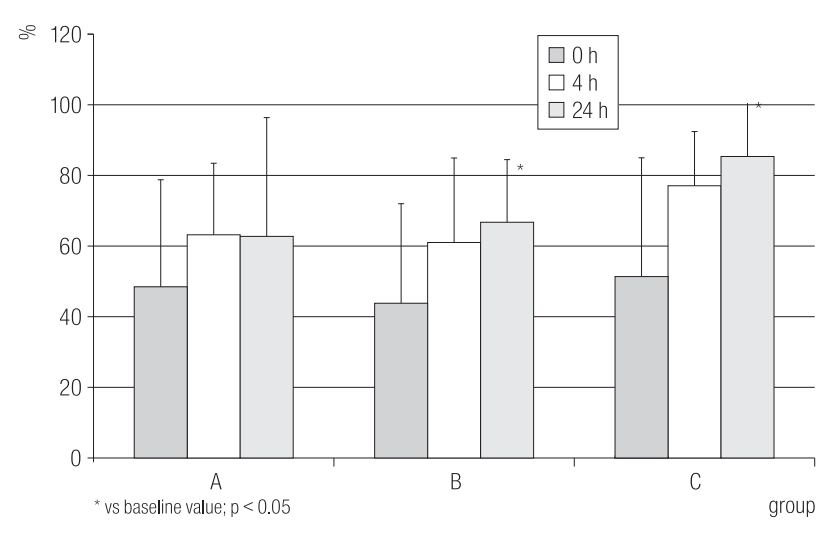

Fig. 5. Changes in neutrophil proportion after ICHT-F.

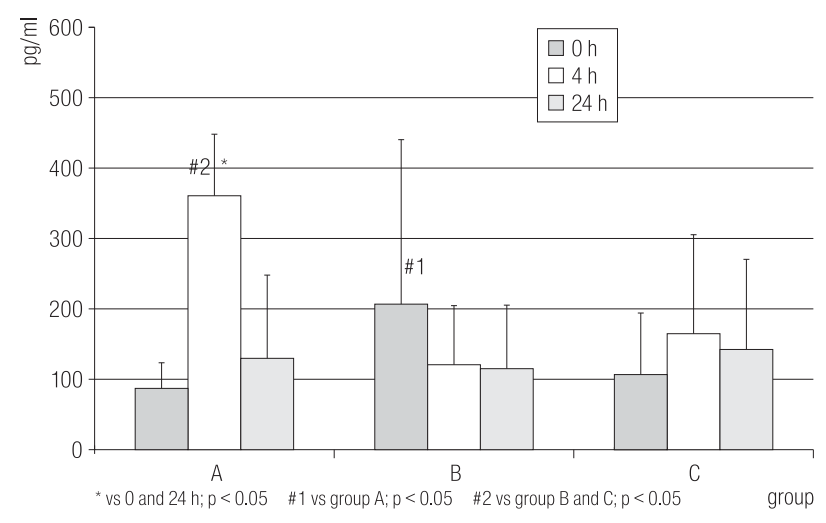

Fig. 6. IL-18 levels after the provocation with flours.

the level of this cytokine was higher than in Group A(Fig. 6). There was a significant difference in IL-18 level at the $4 \mathrm{~h}$ timepoint; the level of this cytokine was higher in Group A than in Groups B and C $\left(\mathrm{F}_{2.25}=6.18 ; \mathrm{p}<0.05\right)$.

A significant relationship was noted in Group A between the proportion of basophils $4 \mathrm{~h}$ after ICHT-F and IL-18 level measured $24 \mathrm{~h}$ after the test. However, no significant relationship was found in this group between the total eosinophil count, the proportion of eosinophils, and IL-18 level at any time-point ( $p>0.05)$.

In Group B, a significant correlation was observed between the proportion of neutrophils before ICHT-F and IL-18 level $24 \mathrm{~h}$ after the challenge $(\mathrm{r}=0.71 ; \mathrm{p}<0.05)$.

\section{DISCUSSION}

The present study demonstrated that in patients diagnosed with OAA, the ICHT-F induced a significant increase in the proportion of basophils during the late phase of allergic inflammation. Twenty-four hours after the provocation with flour allergens, basophil proportion was also significantly higher in Group A than in Group C. Basophils play a significant role in allergic response [17]. They have been reported in the respiratory tract of patients dying of asthma, during the exacerbations of this disease and during the late asthmatic response to the allergen [18-20]. It is estimated that in the late asthmatic reaction, more than $95 \%$ of all metachromatic cells in the bronchoalveolar lavage fluid are basophils [20,21].

In the present study, we found an increase both in the total eosinophil count and in the eosinophil proportion after ICHT-F in the group of subjects with OAA; but the findings were not statistically significant. However, the total eosinophil count was statistically higher in Group A than in Groups B and C at both the time-points after the provocation, and eosinophil proportion was also higher in Group A than in Group C both at the $4 \mathrm{~h}$ and $24 \mathrm{~h}$ time-points. The role of eosinophils in allergic diseases is well-documented [22]. The toxic granule-derived proteins are responsible for tissue damage [22]. Eosinophil influx into nasal and bronchial mucosa has been observed after ICHT in subjects sensitized to low- and high-molecular weight allergens [23-25]. In the study reported, the provocation with flour allergens induced a significant increase in the proportion of neutrophils in NLF $24 \mathrm{~h}$ after the test both in the subjects from Group B and C. The presence of these cells supports the non-specific character of the inflammatory process developing in the nasal mucosa of these subjects. Our earlier observations [8] indicate that neutrophils are not involved in the chronic airway inflammation induced by flour allergens.

This study has for the first time analyzed the levels of IL-18 in nasal washings before and after ICHT-F performed on subjects with flour-induced OAA. The findings revealed that ICHT-F had produced statistically significant changes in IL-18 concentration among the subjects diagnosed with OAA; the level of this cytokine was higher $4 \mathrm{~h}$ after ICHT-F than before and $24 \mathrm{~h}$ after the challenge. In Group A, the concentration of this cytokine was also significantly higher than in Groups B and C at the $4 \mathrm{~h}$ time-point. 
The effects of IL-18 on airway inflammation are not easily predicted since this cytokine may promote both Th1 and Th2 response. This proinflammatory cytokine related to the IL-1 family [26] is responsible for up-regulation of Th1-cytokines, such as IL-2, IFN and granulocyte-macrophage colony stimulating factor (GMCSF) [27], but can also increase allergic sensitization, airway eosinophilia and serum IgE Th2 cytokines [5,7,28].

A significantly decreased level of IL-18 was found in the bronchoalveolar lavage fluid derived from asthmatics, compared to healthy controls [29], but Tanaka et al. [30] reported high serum IL-18 levels in patients with acute exacerbations of asthma. Also Verhaeghe et al. [7] found not only a persistent increase of this cytokine in the course of the pollen season compared to baseline values, but also in persistent allergic rhinitis compared to seasonal allergic rhinitis.

Our findings suggest that IL-18 may have induced Th2 response in subjects with positive specific inhalatory challenge test (Group A). Twenty-four hours after ICHT-F in Group A, the level of IL-18 correlated with the proportion of basophils at the $4 \mathrm{~h}$ time-point. These cells are major inducers of allergic inflammation [18-20]. Yoshimoto et al. [31] has demonstrated that IL-18 has a potential to stimulate basophils to release large amounts of IL-4 and IL-13 in vitro in the presence of IL-3. While IL-4 plays an important role in the primary allergen sensitization process, IL-13 is important in the secondary exposure to allergen [32].

Our data did not reveal a significant relationship between the level of IL-18 and the total eosinophil count or the proportion of these cells in the subjects with OAA (Group A). However, eaosinophil proportion and total count were higher in Group A than in Group C during the late phase of allergic inflammation. A significant correlation was also observed between the proportion of neutrophils before ICHT-F in the subjects with atopic asthma and rhinitis (Group B) and IL-18 level $24 \mathrm{~h}$ after the test. We presume that in the subjects with negative ICHT, not sensitized to an occupational allergen, the increased neutrophil recruitment into the airways might have been caused by an increased expression of mRNAs for IL-17 [33]. IL-17 has a potential to increase neutrophil recruitment by realizing several different CXC chemokines including GCP-2, Gro- $\alpha$ [34].

We also found a significantly higher level of IL-18 before ICHT in nasal washings from subjects with atopic asthma than with OAA. Most of the subjects in Group B were sensitized to Dermatophagoides pteronyssinus and reported the presence of persistent allergic symptoms. Thus, we presume that the observed enhanced expression of IL-18 before the challenge in this group might be explained by different regulation of pro-inflammatory cytokines in persistent allergic inflammation and in inflammation induced by a single antigenic challenge. Further studies are necessary to elucidate the role of IL-18 in the induction of allergic inflammation.

To conclude, this is the first study demonstrating a decreased expression of IL-18 in NLF from subjects with flour-induced OAA. The findings imply that in persistent allergic diseases the relationship between Th1/Th2 cells is more complicated.

\section{REFERENCES}

1. Kohno K, Kataoka J, Ohtsuki T, Suemoto T, Okamoto I, Usui M, et at. IFN-gamma-inducing factor (IGIF) is a costimulatory factor on the activation of Th1 but not Th2 cells and exerts its effect independently of IL-12. J Immunol 1997;158:1541-50.

2. Wild JS, Sigounas A, Sur N, Siddiqui MS, Alam R, Kurimoto $\mathrm{M}$, et al. IFN- $\gamma$-inducing factor (IL-18) increases allergic sensitization, serum IgE, Th2 cytokines, and airway eosinophilia in a mouse model of allergic asthma. J Immunol 2000;164:2701-10.

3. Okamura H, Tsutsui H, Kashiwamura S, Yoshimoto T, Nakanishi K. Interleukin-18: a novel cytokine that augments both innate and acquired immunity. Adv Immunol 1998;70:281-312.

4. Yoshimoto T, Okamura H, Tagawa YI, Iwakura Y, Nakanishi K. Interleukin-18 together with IL-12 inhibits IgE production by induction of interferon $\gamma$ production from activated B cells. Proc Natl Acad Sci USA 1997;94:3948-53.

5. Kumano K, Nakao A, Nakajima H, Hayashi F, Kurimoto M, Okamura H, et al. Interleukin-18 enhances antigen-induced 
eosinophil recruitment into mouse airways. Am J Respir Crit Care Med 1999;160:873-8.

6. Venge P. Monitoring the allergic inflammation. Allergy 2004;59:26-32.

7. Verhaeghe B, Gevaert P, Holtappels G, Lukat KF, Lange B, Van Cauwenberge P, et al. Up-regulation of IL-18 in allergic rhinitis. Allergy 2002:57:825-30.

8. Walusiak J, Hanke W, Górski P, Pałczyński C. Respiratory allergy in apprentice bakers: do occupational allergies follow up the allergic march? Allergy 2004;59:442-50.

9. Davies DE, Wicks J, Powell RM, Puddicombe SM, Holgate ST. Airway remodeling in asthma: new insights. J Allergy Clin Immunol 2003;111:215-25; quiz 226.

10. Baur X, Degens PO, Sander I. Baker's asthma: still among the most frequent occupational respiratory disorders. J Allergy Clin Immunol 1998;102:984-97.

11. Dreborg S, Frew AJ, editors. Allergen standardization and skin tests. Allergy 1993;48(Suppl 14):49-82.

12. Johansson SG, Hourihane JOB, Bousquet J, BruijnzeelKoomen C, Dreborg S, Haahtela T, et al. A revised nomenclature for allergy. An EAACI position statement from the EAACI nomenclature task force. Allergy 2001;56:813-24.

13. Reininger R, Swoboda I, Bohle B, Hauswirth AW, Valent P, Rumpold $\mathrm{H}$, et al. Characterization of recombinant cat albumin. Clin Exp Allergy 2003;33:1695-702.

14. Wihl JA. Methodological aspects of nasal allergen challenge based on tree pollen immunotherapy study. Allergy 1986;41:357-64.

15. Pałczyński C, Walusiak J, Ruta U, Górski P. Occupational asthma and rhinitis due to glutaraldehyde: changes in nasal lavage fluid after specific inhalatory challenge test. Allergy 2001;56:1186-91.

16. Greiff L, Pipkorn U, Alkner U. The nasal pool device applies controlled concentrations of solution on human nasal airway mucosa and secretions. Clin Exp Allergy 1990;20:253-9.

17. VAN Drunen CM, Fokkens WJ. Basophils and mast cells at the centre of the immunological response. Allergy 2006;61:273-5.

18. Koshino T, Teshima S, Fukushima N, Takaishi T, Hirai K, Miyamoto Y, et al. Identification of basophils by immunohistochemistry in the airways of postmortem case of fatal asthma. Clin Exp Allergy 1993;23:919-25.
19. Maruyama N, Tamura G, Aizawa T, Ohrui T, Shimura S, Shirato K, et al. Accumulation of basophils and their chemotactic activity in the airways during natural airway narrowing in asthmatic individuals. Am J Respir Crit Care Med 1994;150: 1086-93.

20. Guo CB, Liu MC, Galli SJ, Bochner BS, Kagey Sobotka A, Lichtenstein LM. Identification of IgE-bearing cells in the late-phase response to antigen in the lung as basophils. Am J Respir Cell Mol Biol 1994;10:384-90.

21. Liu MC, Hubbard WC, Proud D, Stealey BA, Galli SJ, Kagey-Sobotka A, et al. Immediate and late inflammatory responses to ragweed antigen challenge in the peripheral airways in allergic asthmatics. Am Rev Respir Dis 1991;144:51-8.

22. Venge P. Monitoring the allergic inflammation. Allergy 2004;59: 26-32.

23. Pałczyński C, Walusiak J, Ruta U, Górski P. Nasal provocation test in the diagnosis of natural rubber latex allergy. Allergy 2003;55:34-41.

24. Pałczyński C, Walusiak J, Krakowiak A, Szymczak W, Wittczak T, Ruta U, et al. Nasal lavage fluid examination in diagnostics of occupational allergy to chloramine. Int J Occup Med Environ Health 2003;16:231-40.

25. Krakowiak A, Dudek W, Ruta U, Pałczyński C. Occupational eosinophilic bronchitis without asthma due to chloramine exposure. Occup Med 2005;55:396-8.

26. Lauw FN, Dekkers PEP, TE Velde AA, Speelman P, Levi M, Kurimoto M, et al. Interleukin-12 induces sustained activation of multiple host inflammatory mediator systems in chimpanzees. J Infect Dis 1999;176:646-52.

27. Dinarello CA. IL-18: a $T_{H 1}$ inducing, proinflammatory cytokine and new member of the IL-1 family. J Allergy Clin Immunol 1999;103:11-24.

28. Gracie JA, Robertson SE, Mcinnes IB. Interleukin-18. J Leukoc Biol 2003;73:213-24.

29. Ho LP, Davies M, Denison A, Wood FT, Greening AP. Reduced interleukin-18 levels in BAL, specimens from patients with asthma compared to patients with sarcoidosis and healthy control subjects. Chest 2002;121:1421-6.

30. Tanaka H, Miyazaki N, Oashi K, Teramoto S, Shiratori M, Hashimoto M, et al. IL-18 might reflect disease activity in mild and moderate asthma exacerbation. J Allergy Clin Immunol 2001;107:331-6. 
31. Yoshimoto T, Tsutsui H, Tominaga K, Hoshino K, Okamura H, Akira S, et al. IL-18, although antiallergic when administered with IL-12, stimulates IL-4 and histamine release by basophils. Proc Natl Acad Sci USA 1999;96:13962-6.

32. Kips JC. Cytokines in asthma. Eur Respir J 2001;18(Suppl 34):24-33.
33. Linden A. Role of IL-17 and the neutrophil in asthma. Int Arch Allergy Immunol 2001;126:179-84.

34. Laan M, Cui ZH, Hoshino H, Lotvall J, Sjostrand M, Gruenert DC, et al. Neutrophil recruitment by human IL-17 via $C-X$-C chemokine release in the airways. J Immunol 1999;162:2347-52. 